\title{
Effect of Organic and Inorganic Priming on Seed Yield Parameters of Chickpea
}

\author{
B. Pavan Naik and V. Blessy* \\ Department of Genetics and Plant Breeding, Naini Agriculture Institute, \\ SHUATS, Allahabad, India \\ *Corresponding author
}

\section{A B S T R A C T}

\section{Keywords \\ Chickpea (Cicer arietinum $\mathrm{L}$.), Biopriming, Fungicides \\ Article Info \\ Accepted: \\ 26 July 2018 \\ Available Online: \\ 10 August 2018}

The present investigation was carried out at Field Experimentation Centre and, Department of Genetics and Plant Breeding, Naini Agriculture Institute, SHUATS, Allahabad during Rabi, 2016 to 17 evaluate the "Effect of organic and inorganic priming on seed yield parameters of chickpea (Cicer arietinum L.)". Five treatments gave the significant results. T1 (Trichoderma harzianum) showed significant performance for field emergence (85.83), plant height (77.8), number of plants per plot (24.5), number of primary branches (3.25), number of pods per plant (45), seed weight per plant (17.61) and seed yield per plot (135.89) in organic priming followed by T4 (Carbendazim) in inorganic priming compared to untreated control.

\section{Introduction}

The word Cicer is a derivative from the Greek word kiros referring to a well known roman family Cicero. Arietinum is derived from the latin word arise meaning ram which refers to the ram's head shape of the chickpea (Singh, 1985).

Chickpea (Cicer arietinum L.) is known by different names in various countries such as gram, chana, bengalgram, kadleetc. Chickpea is an important Rabi season legume having extensive geographical distribution. Chickpea is a diploid species with a chromosome number $2 \mathrm{n}=16$. It is a self-pollinated crop and it belongs to sub family Papilionoideae and tribe, Cicereae of the family leguminaceae. Later on, Cicer was considered to belong to tribe, Viceae Alef. Chickpea is the third most important pulse crop in the world after beans and peas. It is cultivated on an area of 12 million hectares with 8.9 million tones of annual production. Chickpea plays an important role to improve soil fertility by fixing atmospheric nitrogen with the help of root nodules (Anabessa et al., 2006). Chickpea is native of south-eastern Turkey and Syria (Saxena and Singh, 1987). 
Seed priming is one of the methods of increasing yield in different crops including legume. This priming may be conducted by using water or some chemical substances; increasing seed quality and germination. High germination percentage and simultaneous germination are two desired traits in mechanized agriculture. Complementary seed priming is a water balance dependent process which is conducted by soaking seeds in water for a certain time to accelerate their germination. The complementary seed priming stimulates many metabolic processes related to seed germination (Rastin, 2013).

Rapid germination and emergence is an important factor of successful establishment. It is reported that seed priming is one of the most important developments to help rapid and uniform germination and emergence of seeds and to increase seed tolerance to adverse environmental conditions Heydecker et al., (1973), Harris et al., (2001). Seed priming has presented promising, and even surprising results, for many seeds including the legume seeds (Bradford, 1986). Seed treatment is the concept of the management practices for invigorating seed viability and vigor throughout the production cycle of the seed. Seed priming is an age old practice, practiced million years ago by Greeks. The word was coined by Heydecker (1973) for soaking, drying seed treatments. Priming coupled with biopriming agents or growth promoters in low doses can help check certain diseases. Biopriming seed treatment is also potentially prominent technique to induce profound changes in plant characteristics and to encourage more uniform seed germination and plant growth after seed coating with certain fungi and bacteria (Entesari et al., 2013).

\section{Materials and Methods}

In the present investigation, GNG-1581 variety of chickpea were grown in the Rabi season of 2016 at the field experimentation center of the Department of Genetics and Plant Breeding, Sam Higginbottom University of Agriculture, Technology \& Sciences (Formerly Allahabad Agricultural Institute), Allahabad (U.P) in the year 2016 rabi with 5 treatments 4 replications using RBD technique.

\section{Treatment Description}

\begin{tabular}{|l|l|}
\hline Treament & Description \\
\hline T1 & Trichoderma harzianum @0.6\% \\
\hline T2 & Pseudomonas fluorescens @ 0.6\% \\
\hline T3 & Carbendazim 25\% WS @ 0.2\%+ Mancozeb 50\% \\
\hline T4 & Carbendazim @ 0.2\% \\
\hline T5 & Control \\
\hline
\end{tabular}

\section{Details of method of priming}

Chickpea seeds were presoaked for 8 hours in water. Then all seeds were treated with rhizobium culture @ $10 \mathrm{~g} / \mathrm{kg}$ seeds using natural gum. After that seeds were treated with bioagents or fungicides as per the treatments given above and shade dried overnight by spreading on ground at room temperature. The statistical analysis and variance due to different sources was worked out according to Panse and Sukhatme (1967).

\section{Results and Discussion}

The analysis of variance showed significant differences among different characters. This indicates the presence of variability among the treatments (Fig. 1-8; Table 1 and 2). 
Table.1 Mean performance of quantitative characters in chickpea

\begin{tabular}{|c|c|c|c|c|c|c|c|c|c|}
\hline S.NO & Treatments & $\begin{array}{l}\text { Field } \\
\text { emergence }\end{array}$ & $\begin{array}{l}\text { Plant height } \\
(\mathrm{cm})\end{array}$ & $\begin{array}{l}\text { Number of } \\
\text { plants }\end{array}$ & $\begin{array}{l}\text { Days to } \\
50 \% \\
\text { flowering }\end{array}$ & $\begin{array}{l}\text { Primary } \\
\text { branches }\end{array}$ & $\begin{array}{l}\begin{array}{l}\text { Number } \\
\text { pods } \\
\text { plants }\end{array} \\
\end{array}$ & $\begin{array}{l}\text { Seed weight } \\
\text { per plot }\end{array}$ & Seed yield \\
\hline 1 & $\mathrm{~T} 1$ & 85.83 & 77.80 & 24.50 & 90.75 & 3.25 & 45 & 17.61 & 135.89 \\
\hline 2 & $\mathrm{~T} 2$ & 66.67 & 53.60 & 18.75 & 100.75 & 2.5 & 28.75 & 10.36 & 70.97 \\
\hline 3 & T3 & 74.16 & 68.15 & 21 & 98.50 & 2.75 & 33.25 & 11.95 & 91.4 \\
\hline 4 & $\mathrm{~T} 4$ & 80 & 75.80 & 22.25 & 95.75 & 3 & 38.25 & 13.97 & 103.67 \\
\hline 5 & T5 & 60 & 40.60 & 11.75 & 101.25 & 1.75 & 21.5 & 6.79 & 43.23 \\
\hline \multicolumn{2}{|c|}{ Mean } & $73.33^{*}$ & $63.19 *$ & $19.65^{*}$ & $97.4^{*}$ & $2.65^{*}$ & $33.35^{*}$ & $12.17 *$ & $89.03^{*}$ \\
\hline \multirow[t]{2}{*}{ Range } & Max. & 85.83 & 77.80 & 24.50 & 101.25 & 3.25 & 45 & 17.61 & 135.89 \\
\hline & Min. & 60 & 40.60 & 11.75 & 90.75 & 1.75 & 21.5 & 6.79 & 43.23 \\
\hline \multicolumn{2}{|c|}{ CD $5 \%$} & 12.27 & 10.88 & 3.84 & 1.95 & 1.37 & 5.7 & 3.83 & 27 \\
\hline \multicolumn{2}{|c|}{ SE (m) } & 3.94 & 3.49 & 1.23 & 0.62 & 0.39 & 1.83 & 1.23 & 8.67 \\
\hline
\end{tabular}

T0=control, T1=Trichoderma harzianum@ 0.6\%, T2=Pseudomonas fluorescens@ 0.6\%, T3=Carbendazim 25\% WS @ 0.2\%+ Mancozeb 50\%, T4=Carbendazim @0.2\%.

Table.2 Analysis of variance characters

\begin{tabular}{|l|l|l|l|l|}
\hline S.NO & Characters & Mean sum of squares & \multicolumn{2}{l|}{} \\
\cline { 3 - 5 } & & Treatment(d.f. =4) & Replication(d.f. =3) & Error(d.f.=12) \\
\hline 1 & Field emergence & $1694.53^{*}$ & 115.43 & 745.57 \\
\hline 2 & Number of plants & $381.30^{*}$ & 18.15 & 73.10 \\
\hline 3 & Plant height $(\mathrm{cm})$ & $3997.35^{*}$ & 106.12 & 586.22 \\
\hline 4 & Days to 50\% flowering & $296.80^{*}$ & 11.20 & 18.80 \\
\hline 5 & Primary branches & $5.30^{*}$ & 1.75 & 7.50 \\
\hline 6 & Number of pods per plot & $1285.30^{*}$ & 54.55 & 160.70 \\
\hline 7 & Seed weight $($ gm) & $260.58^{*}$ & 9.53 & 72.71 \\
\hline 8 & Seed yield & $19359.43^{*}$ & 509.92 & 3614.05 \\
\hline
\end{tabular}

* Significant at $5 \%$ level of significance 
Fig.1 Histogram depicting mean performance for Field emergence

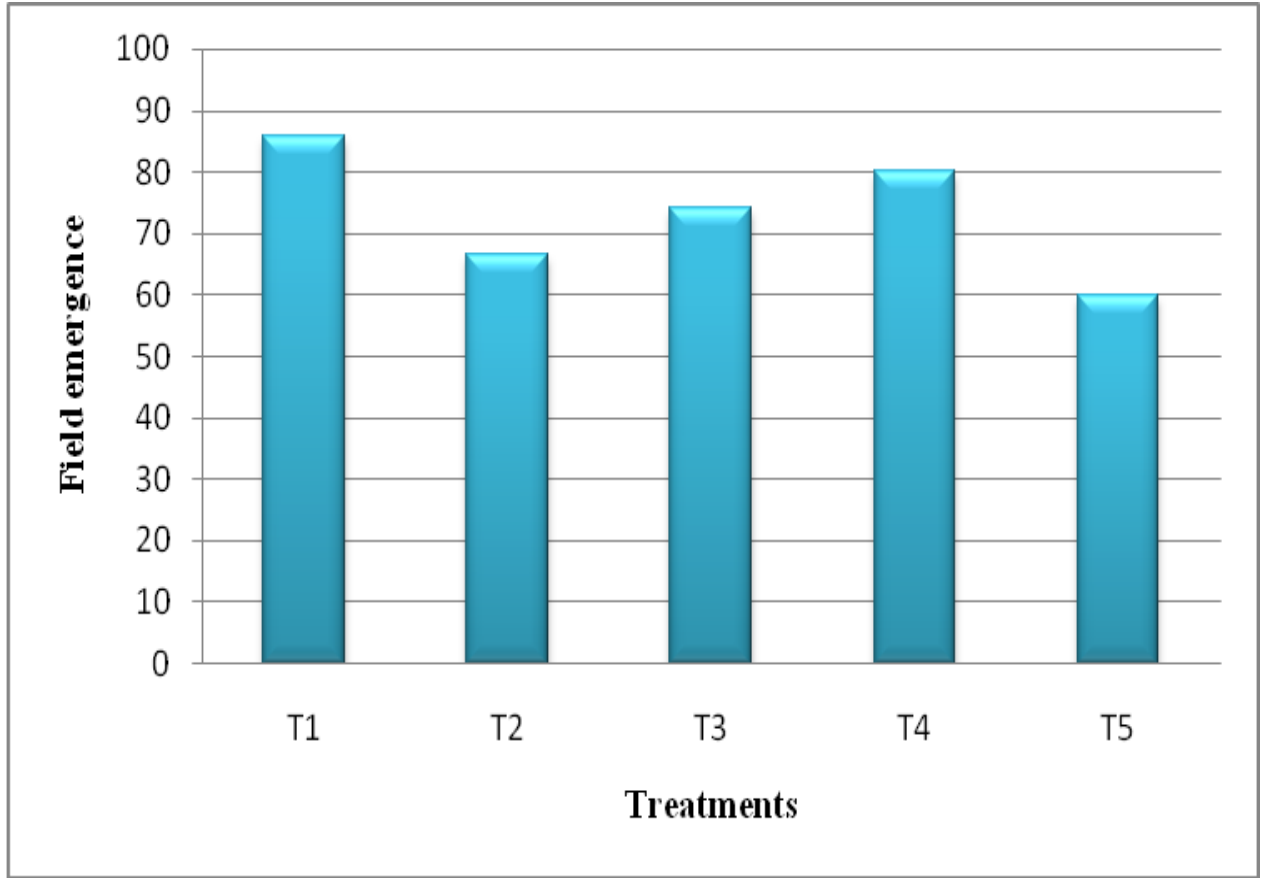

Fig.2 Histogram depicting mean performance for Number of Plants per plot

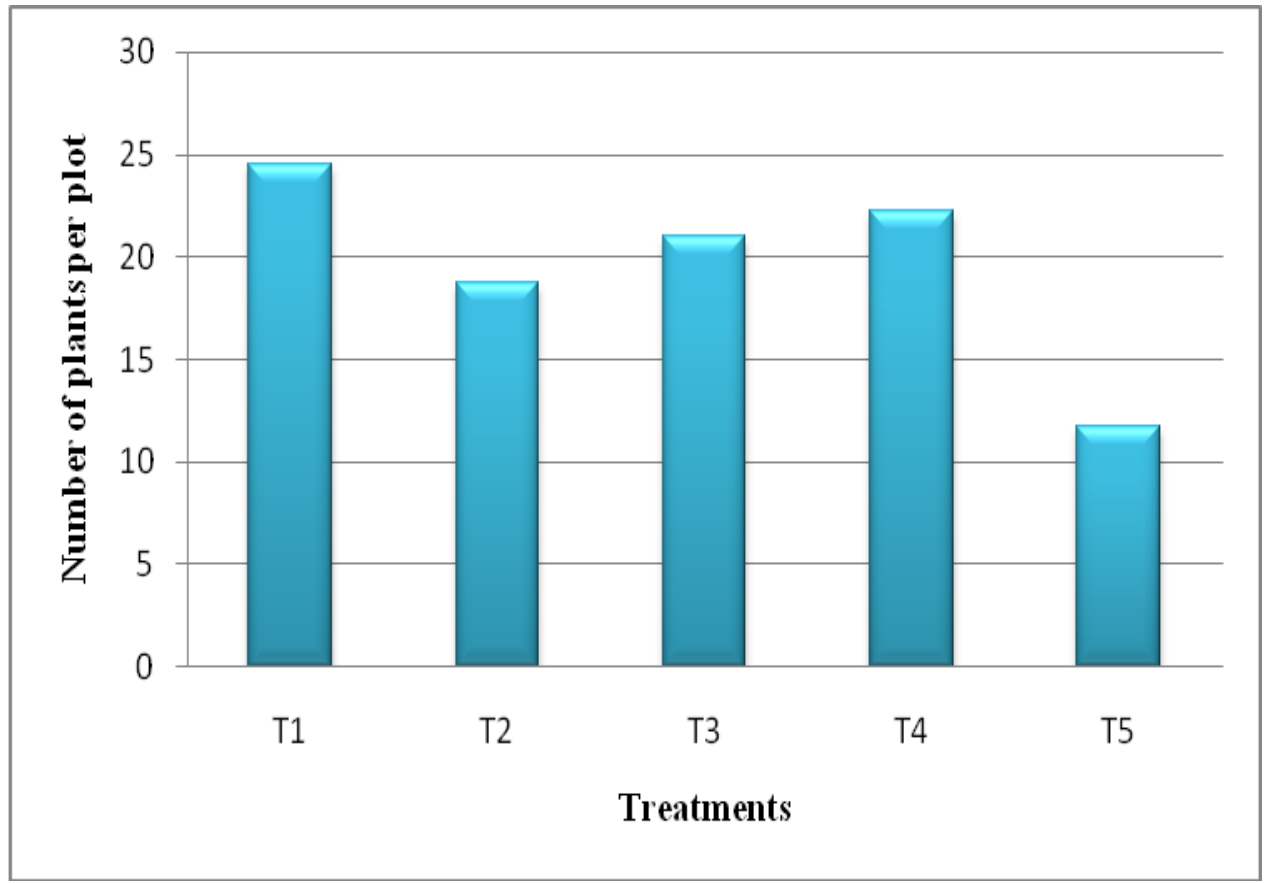

T0=control, T1=Trichoderma harzianum@ 0.6\%,T2=Pseudomonas fluorescens @ 0.6\%, T3=Carbendazim 25\% WS @ 0.2\% + Mancozeb 50\%, T4=Carbendazim @0.2\%. 
Fig.3 Histogram depicting mean performance for Plant height

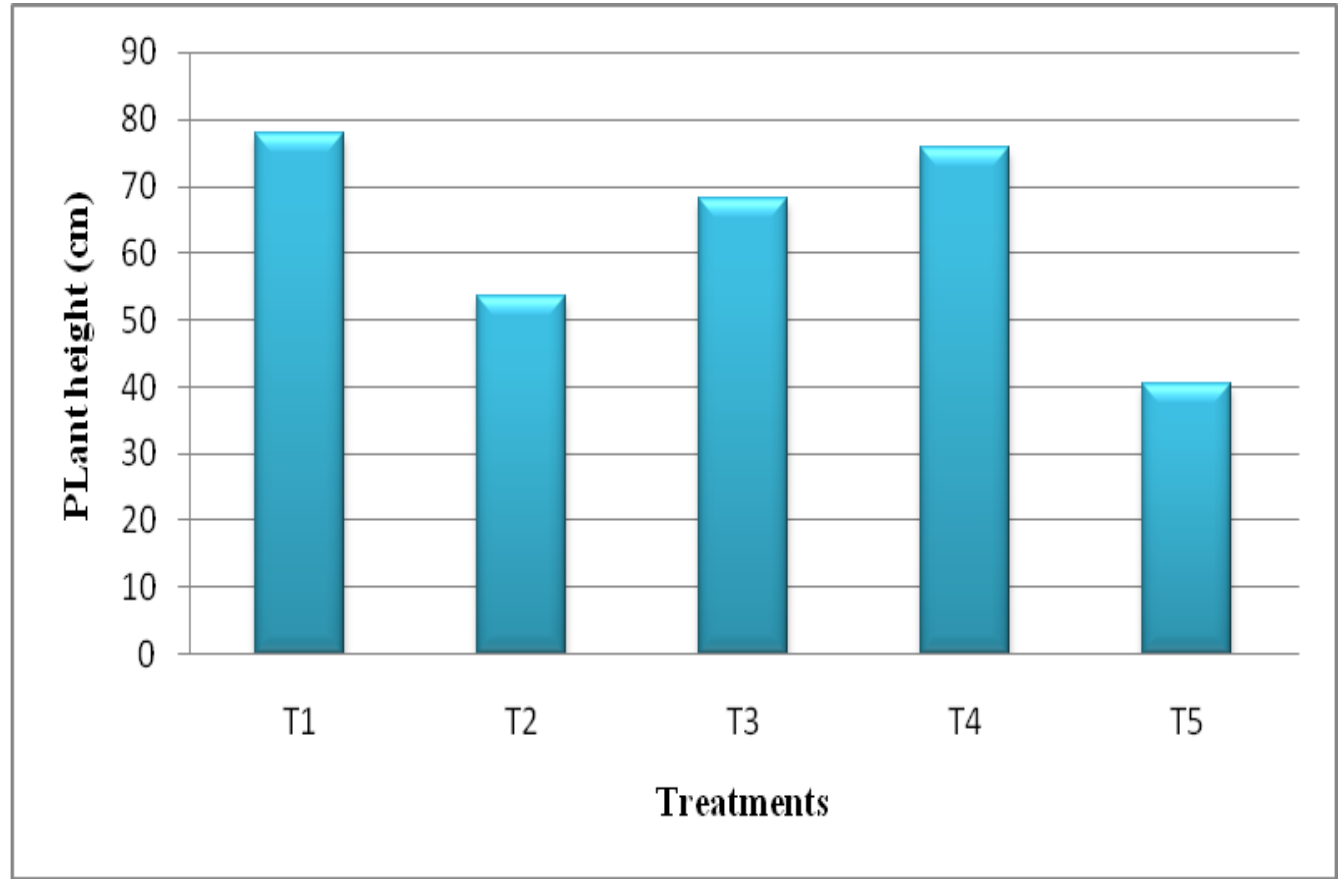

Fig.4 Histogram depicting mean performance for Days to $50 \%$ flowering

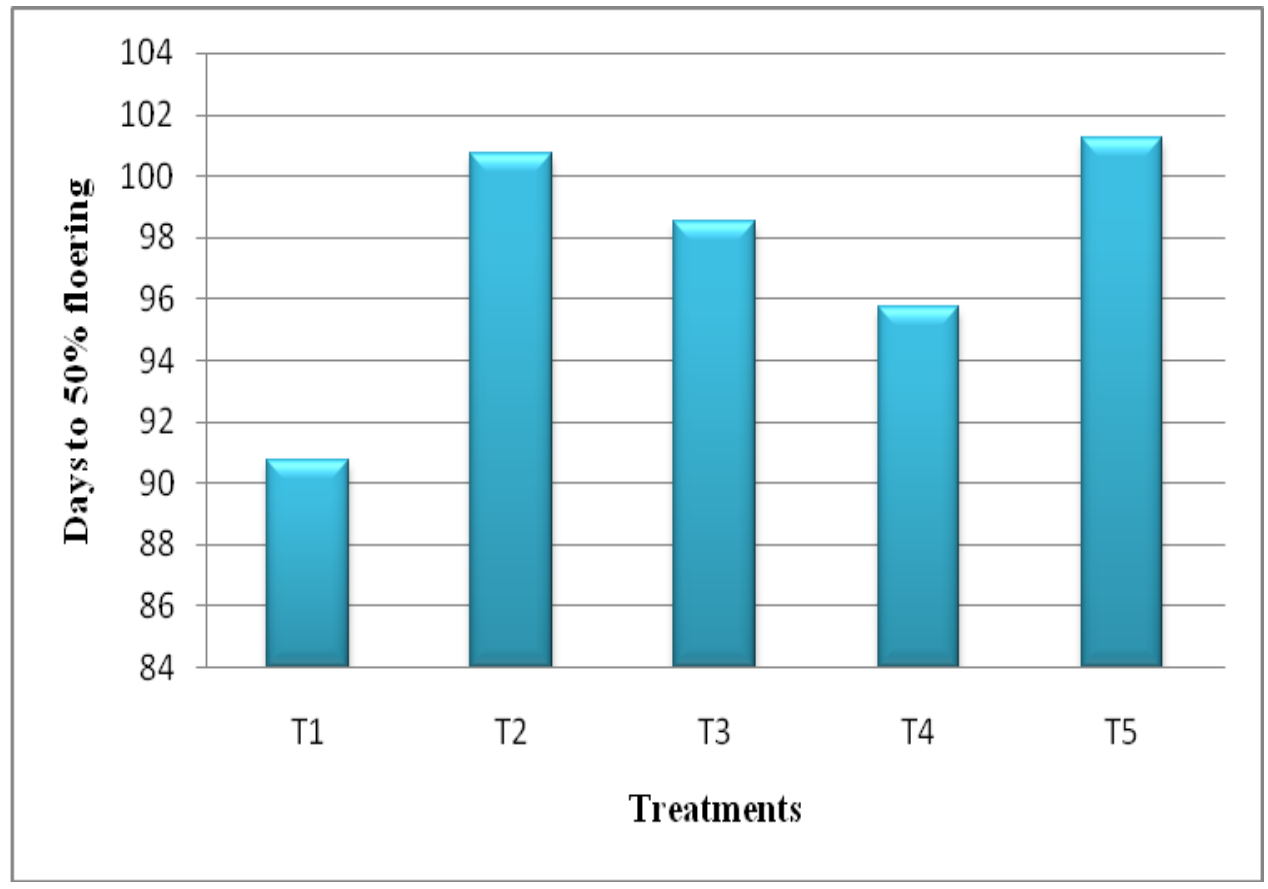

T0=control, T1=Trichoderma harzianum@0.6\%,T2=Pseudomonas fluorescens@ 0.6\%, T3=Carbendazim 25\% WS@0.2\% + Mancozeb 50\%, T4=Carbendazim @0.2\%. 
Fig.5 Histogram depicting mean performance for primary branches/plant

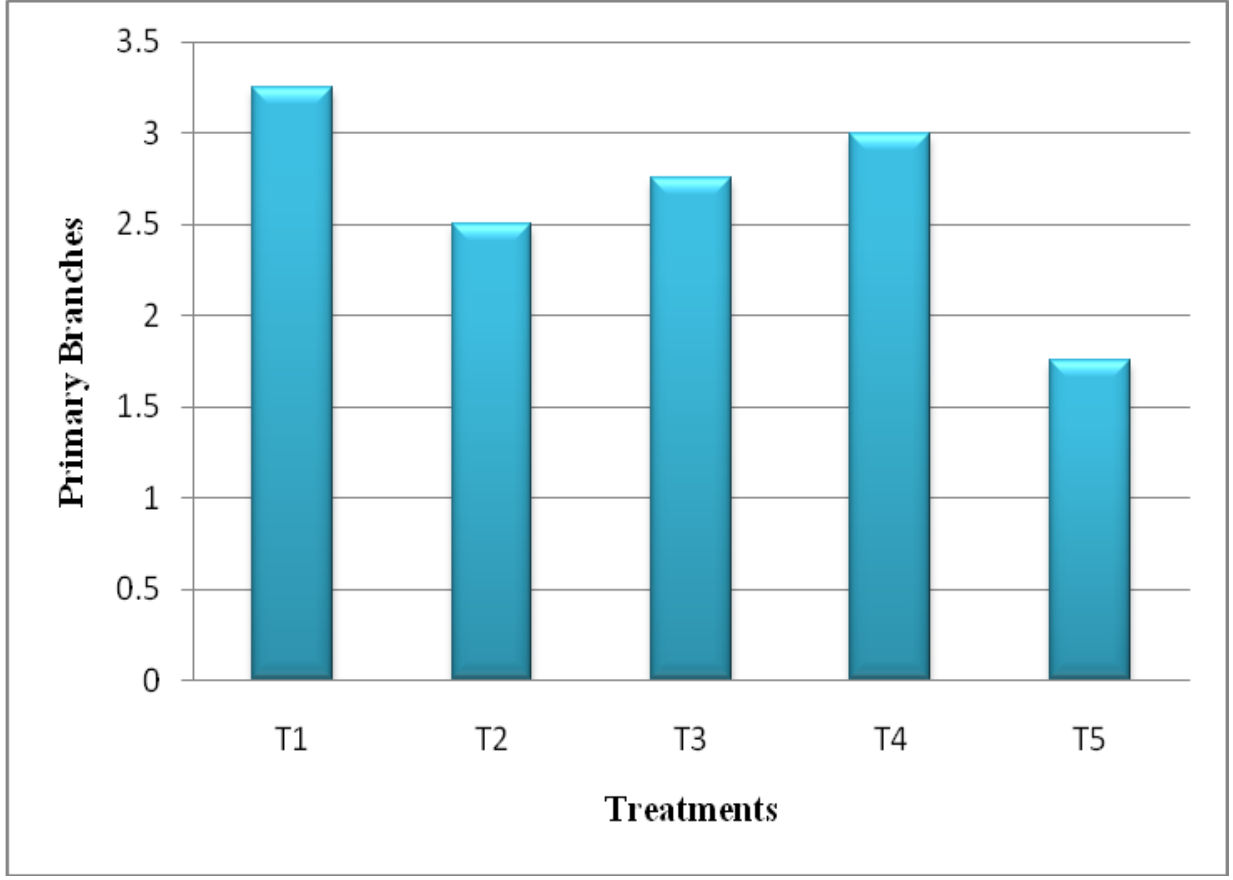

Fig.6 Histogram depicting mean performance for pods/plant

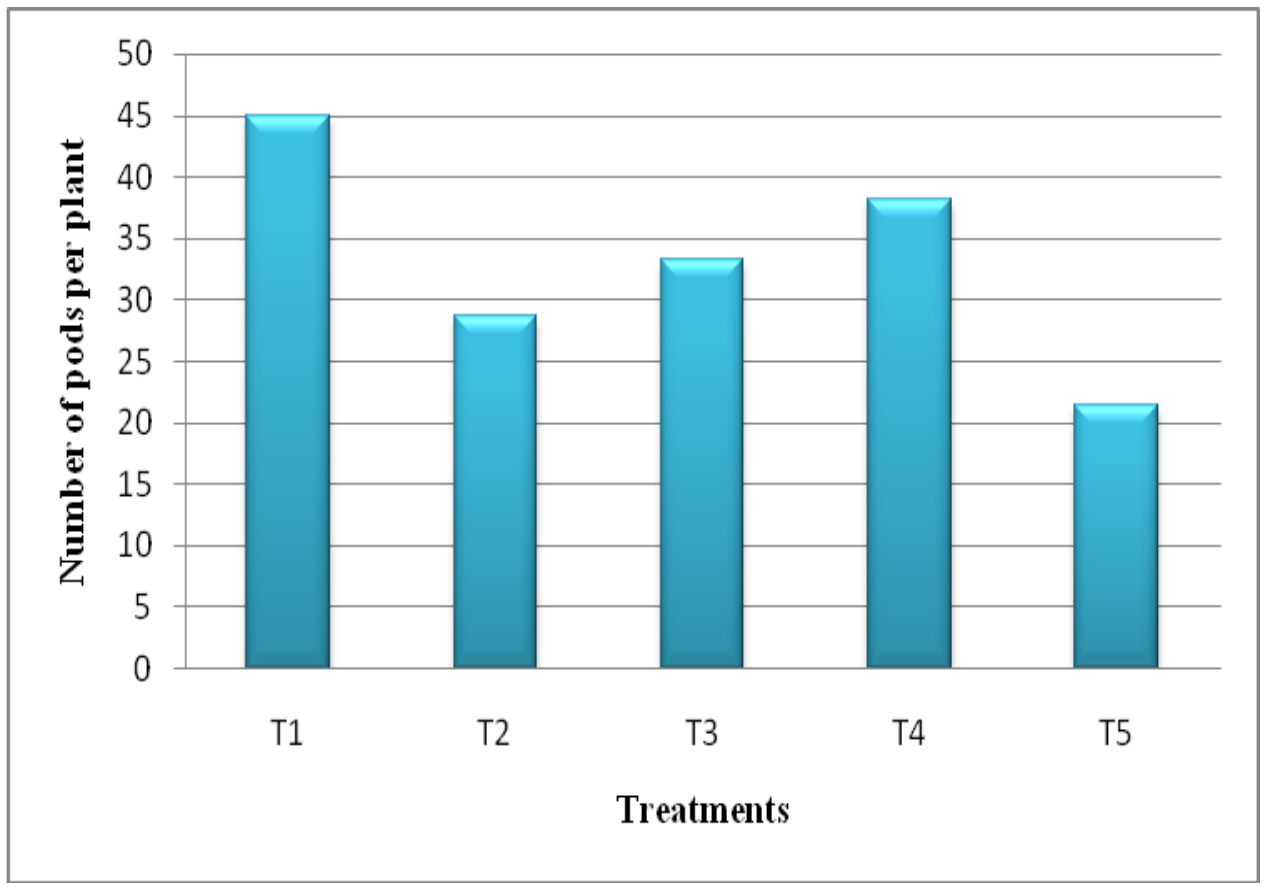

T0=control, T1=Trichoderma harzianum@0.6\%,T2=Pseudomonas fluorescens@ 0.6\%, T3=Carbendazim 25\% WS @ 0.2\% + Mancozeb 50\%, T4=Carbendazim @0.2\%. 
Fig.7 Histogram depicting mean performance for Seed weight/plant

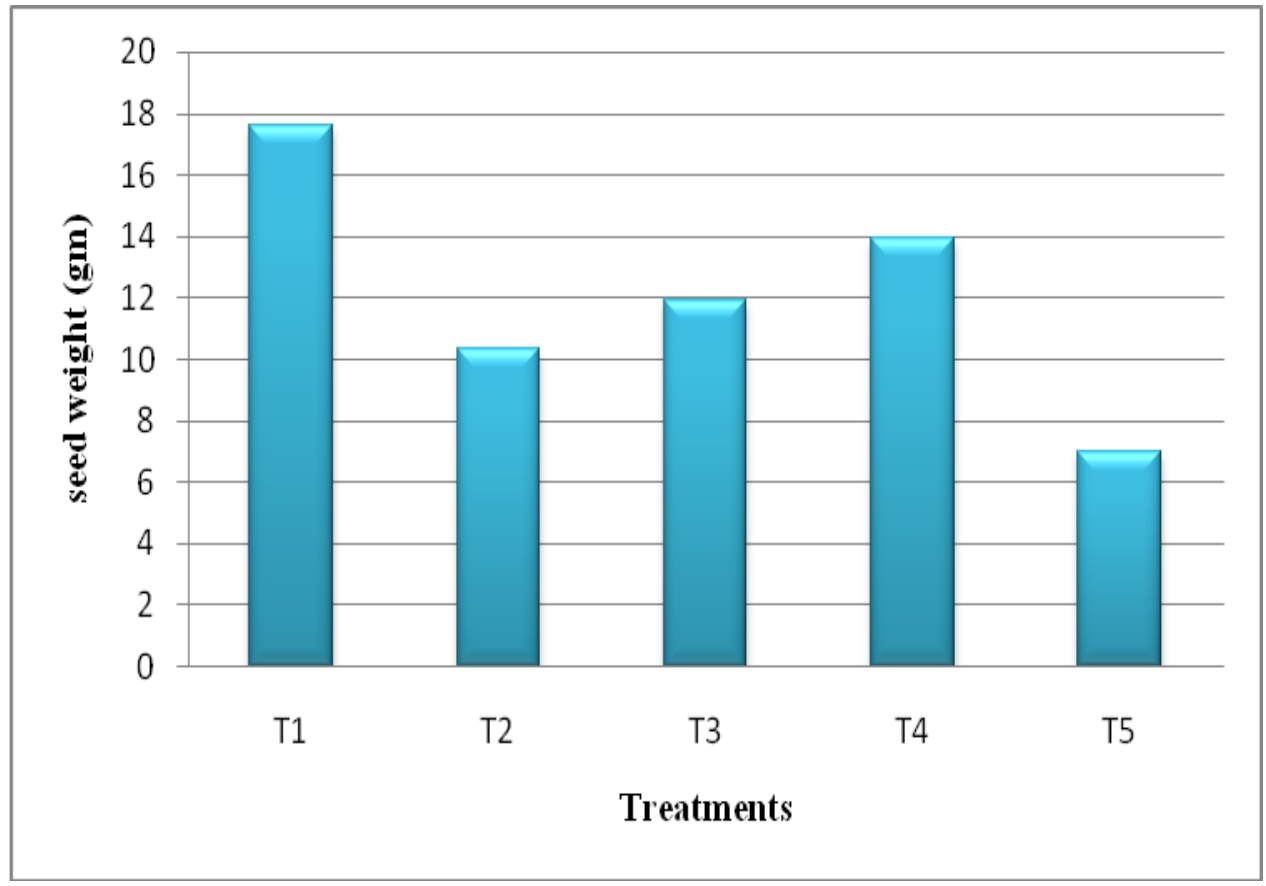

Fig.8 Histogram depicting mean performance for Seed yield/plot

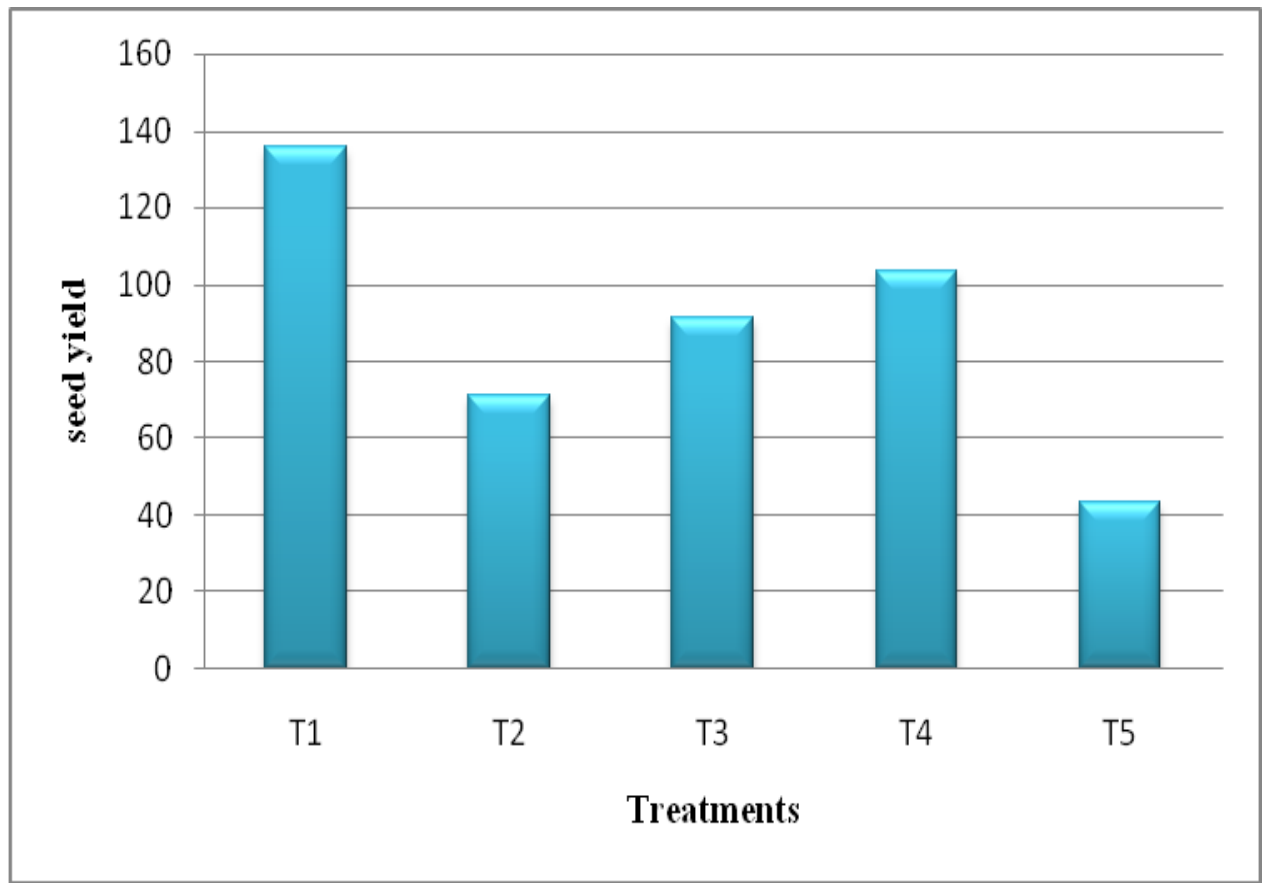

$\mathrm{T} 0=$ control, T1=Trichoderma harzianum@0.6\%,T2=Pseudomonas fluorescens@ 0.6\%, T3=Carbendazim 25\% WS @ 0.2\% + Mancozeb 50\%, T4=Carbendazim @0.2\%. 


\section{Seed quantitative parameters}

\section{Field emergence}

The field emergence was resulted with maximum field emergence was depicted by Trichoderma harzianum 85.83 followed by Carbendazim 80, whereas minimum field emergence was depicted by control 60 .

\section{Number of plants per plot}

The number of plants per plot was resulted with maximum number of plants per plot was depicted by Trichoderma harzianum 24.50 followed by Carbendazim 22.25, whereas minimum number of plants per plot was depicted by control 11.75 .

\section{Plant height (cm)}

The plant height was resulted with maximum plant height was depicted by Trichoderma harzianum 77.80 followed by Carbendazim 75.80 , whereas minimum plant height was depicted by control 40.60 .

\section{Days to 50\% flowering}

The days to $50 \%$ flowering wasresulted with maximum days to $50 \%$ flowering was depicted by control 101.25 followed by Pseudomonas fluorescens 100.75, whereas minimum Days to $50 \%$ flowering was depicted by Trichoderma harzianum 90.75 .

\section{Number of primary branches}

The number of primary branches wasresulted with maximum number of primary branches was depicted by Trichoderma harzianum3.25followed by Carbendazim 3, whereas minimum number of primary branches was depicted by control 1.75 .

\section{Number of pods per plant}

The number of pods per plant was resulted with maximum number of pods per plant was depicted by Trichoderma harzianum 45 followed by Carbendazim 38.25, whereas minimum number of pods per plant was depicted by control 21.5.

\section{Seed weight per plant}

The seed weight per plant was resulted with maximum seed weight per plant was depicted by Trichoderma harzianum 17.61 followed by Carbendazim13.97, whereas minimum seed weight per plant was depicted by control 6.79 .

\section{Seed yield/plot}

The seed yield per plot was resulted with maximum seed yield per plot was depicted by Trichoderma harzianum 135.89followed by Carbendazim 103.67, whereas minimum seed yield per plot was depicted by control 43.23 .

It is concluded from the results of the experiment that among all the treatments, Trichoderma harzianum showed significant performance for field emergence, plant height, number of plants per plot, number of primary branches, number of pods per plant, seed weight per plant and seed yield per plot in organic priming followed by carbendazim in inorganic priming. Therefore, use of Trichoderma harzianum @ $0.6 \%$ and carbendazim@0.2\% are recommended for treating chickpea for better quality, and quantity parameters.

\section{References}

Ashraf, M., and Foolad, M. R. (2005). Presowing seed treatment: A shotgun approach to improve germination, growth and crop yield under saline and none-saline conditions. Advance Agronomy, 88: 223-271. 
Anabesso, Y., Warkentin, T., Vandenberg, A. and Bandra, M. (2006). Heritability and predicted grain from selection in component of crop duration in divergent chickpea. Euphytica, 152(1): 1-8.

Anonymous, (2009). Hindu Survey of Agriculture in India.

Anitha, U. V., Mummigatti and Shamarao Jahagirdar. (2012). Seeds of JS 335 variety were primed with different fungicides and bio-agents and were subjected for seed germination and field performance in order to know the influence of fungicides and biocontrol agents on germination, seedling growth, disease incidence and yield parameters. Indian Journal Agricultural Sciences, 28(1): (20-23).

Basu, R. N., and Dasgupta, M. (1974). Control of seed deterioration in wheat (Triticum aestivum L.). Indian Agriculture, 18(3): 285-288.

Basu, R. N., and Pal, P. (1979). Physicochemical control of seed deterioration in rice. Indian Journal Agricultural Sciences, 49(1): 1-6.

Bradford K. J. (1986) Manipulation of seeds water relations via osmotic priming to improve germination under stress condition. Horticultural science, 59(2):672-676

Beguma, M.M., Sariaha, M., Putehb, A.B., Yasmeen Siddiqui. (2010). Field performance of bio-primed seeds to suppress Colletotrichum truncatum causing damping-off and seedling stand of soybean. Article Biological Control, 53(1):18-23.

Callan, N. W., Mathre, D. E., and Miller, I. B. (1990). Biopriming seed treatment for biological control of Pythium ultimum pre emergence-damping off in sh-2 sweet com. Plant Diseases., 74: 366376.

Callan, N. W., Mathre, D. E. and Miller, J. B. (1991). Field performance of sweet com seed bioprimed and coated with Pseudomonas fluorescens ab254. Horticultural Science, 26: 1163-1165.
Conrath, U., Thulke, O., Ketz, V., Schwindling S. and A. Kohler. (2001). Priming as mechanism in induced systemic resistance of plants. European Journal of plant pathology, 107: 113-119.

Chandra Nayaka, S. R., Niranjana, A.C., Uday Shankar, S., Niranjan Raj, M. S., Reddy, H. S., Prakash and Mortensen. C. N. (2010). Seed biopriming with novel strain of Trichoderma harzianum for the control of toxigenic Fusarium verticillioides and fumonisins in maize. Journal Archives of Phytopathology and Plant protection, issue 3.

El-Mohamedy, M. A., Abd. (2004). Soil Amendment and Seed Biopriming treatment as alternate fungicide for control damping of okra plants. International Journal of Agricultural Technology, 11(5):1240-1255.

El-Mohamedy, R. S. R., Abd Alla M.A., Badiaa, R. (2006). Soil amendment and seed bio-priming treatments as alternative fungicides for controlling root rot diseases on cowpea plants in Nobaria Province. Research Journal of Agriculture Biological Sciences, 2:391398

El-Mohamedy, R.S.R., and Abd El-Baky, M.M.H. (2008). Evaluation of different types of seed treatment on control of root rot disease, improvement growth and yield quality of pea plant in Nobaria Province. Research Journal of Agriculture and Biological Sciences, 4(6): 611-622.

Entesari, M., Sharifzadeh, F., Ahmadzadeh, M., and Farhangfar, M. (2013). Seed biopriming with Trichoderma species and Pseudomonas fluorescens on growth parameters, enzyme activity and nutritional status of soybean. International Journal of Agronomy and Plant Production, 4 (4): 610-19.

Fisher, P. J., Broad, S. A., Clegg, C. D. and Lappin Scott, H. M., (1993). Retention and spread of a genetically engineered pseudomonad in seeds and plants of 
(Zea mays L.) A preliminary study, New Phytology, 124: 101-106.

FAO (2012). http://faostat.fao.org/default. aspx December, 2010 to March, 2011.

FAOSTAT. (2015). Food and Agricultural Organization Statistical Databases, Rome.

Gawade, D. B., Suryawanshi, A. P., Pawar, A. K., Apet K. T., and Devgire S. S., (2009). Field evaluation of fungicides, botanicals and bioagents against anthracnose of soybean. Agriculture Sciences, Digest, 29 (3): 174-177.

Gupta Vikas, Singh Mahender, Kumar Anil, Kumar Jai, Singh B. N. and Jamwal, B. S., (2012). Screening of post-emergence herbicides in Chickpea (Cicer arietinum) under rainfed conditions of Jammu. Legume Research, 35 (4): 320326.

Heydecker, W. (1973). Panel discussionpresowing treatments. Seed Ecology (Edition) W. Heydecker, Butterwort, London., pp.521- 531.

Heydecker, W. (1973). Germination of an idea:

Harris, D. A., Joshi, P. A., Khan, Gothkar, P., and Sodhi, P. S. (1999). On-farm seed priming in semi-arid agriculture development and evaluation in maize, rice and chickpea in India, using participatory methods. Experimental Agriculture, 35: 15-29.

Harris, D., Pathan, A. K., Gothkar, P., Joshi, A., Chivasa, W. and Nyamudeza, P. (2001) On farm seed priming: Using participatory methods to revive and refine a key technology. Agricultural Science Digest, 69: 151-164.

IIPR (2013-2014). Indian Institute of Pulses Research.

ISTA (1999). International rules for seed testing. Seed Science and Technology, 27: 27-31.

IMSCS (2013). Indian Minimum Seed Certification Standards, p 85

Khan, H., Ahmad, S.Q., Forhad, A., Khan, M. S. and Nayar, I. (2006). Genetic variability and correlation among quantitative traits in chickpea
germplasm.
Sarhad
Journal
Agriculture, 22(1): 55-59.

Kerem, A., Gupta, S.K. and Singh, K. (2007). Genetic variability in desi chickpea under normal and sown condition. Journal Research. Punjab Agriculture University, 41(4): 425-428.

Mahajan, G. R. S., Sarlach, S. Japinder and Gill, M. S. (2011). Seed Priming effects on germination, Growth and Yield of Dry Direct-Seeded Rice, Journal of Crop Improvement, 25:4, 409-417.

Moeinzadeh, A., Sharif-Zadeh, M., Ahmadzadeh, F., and Heidari Tajabadi. (2010). Biopriming of sunflower (Helianthus annuus L.) seed with Pseudomonas fluorescens for improvement of seed invigoration and seedling growth. AJCS 4(7):564-570.

Nehal el-mougy Mokhtar, Abdel-Kader. (2008). Long-term activity of bio-priming seed treatment for biological control of faba bean root rot pathogens. Australasian Plant Pathology, 37(5):464-471.

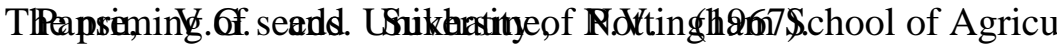
Statistical methods for agricultural workers, LGAR, Publication, New Delhi, 245: 259.

Pathak, G. and Basu, R.N. (1980). Control of seed deterioration in sunflower (Helianthus annus L.). Current Science, 48(2): 67-69.

Punjabi, B., Mandal, A. K. and Basu, R. N. (1982). Maintenance of vigour, viability and productivity of stored barley seed. Seed Research, 10(1): 69-71.

Pan and Amrita Das. (2011). Control of cowpea (Vigna sinensis) root and collar rot (Rhizoctonia solani) with some organic formulations of Trichoderma harzianum and Trichoderma viridae under field condition. The Journal of Plant Protection Sciences, 3(2): 20-25.

Parvatha Reddy, P. (2012). Bio-priming of Seeds. Recent advances in crop protection pp 83-90, Springer, New Delhi.

Raj, N. S., Shetty, N. P. and Shetty, H. S. (2004). Seed biopriming with 
Pseudomonas fluorescens isolates enhances growth of pearl millet plants and induces resistance against downy mildew. International Journal of Pest Management, 50(1):41-48.

Rastin, S. (2013). Effect of seed priming on red bean (Phaseolus calcaratus) growth and yield. Annals of Biological Research, 4(2): 292-296.

Savino. G., Haigh, P. M. and Deleo, P. (1979). Effects of pre-soaking upon seed vigour and viability during storage. Seed Science and Technology, 7: 57-64.

Saha, R. and Basu, R. N. (1981). Maintenance of soybean seed viability by hydration dehydration treatments. Indian Agriculture, 25(4): 275-278.

Singh, U. (1985). Protein isolate from chickpea chemical composition, functional properties and protein characterization. Quality Production Foods Human Nutrition, 35: 339-351.

Saxena, M.C. and Singh, K.B. (1987). Chickpea Commonwealth Agricultural Bureaux.

International, Wallingford, Oxon., OX10 9DE, UK (1987), 127-162.

Saxena, M.C. (1990). Problems and potential of chickpea production in the nineties. In Chickpea in the Nineties Production.
Second International Workshop on Chickpea Improvement, ICRISAT Centre, Patancheru, Andhrapradesh, India.

Saukat, A., Maher, A.B., Anwar, M. and Haqqani, A.M. (2002). Exploitation of genetic variability for grain yields improvement in chickpea. International Journal for Agriculture and Biology, 4(1): 148-149.

Singh, U. S. (2003). Integration of fungal and bacterial antagonists for the management of important plant disease. G. B. Pant University of Agriculture and Technology. Pantnagar.

Singh, Y. (2008). Effect of soil solarization and biocontrol agents on plant growth and management of anthracnose of sorghum. Internat. Indian Journal of Agriculture Sciences, 4: 188-191.

Todele, A., Haddad, N.I., Malhotra, R. and Samarah, N. (2005). Induced polygenic variability in kabuli chickpea lines. Crop. Research, 29(1): 118-128.

Vidhyasekaran, P. and Muthamilan, M., (1995). Development of formulations of Pseudomonas fluorescens for control of chickpea wilt. Plant Diseases, 79: 782 786.

\section{How to cite this article:}

Pavan Naik, B. and Blessy, V. 2018. Effect of Organic and Inorganic Priming on Seed Yield Parameters of Chickpea. Int.J.Curr.Microbiol.App.Sci. 7(08): 4373-4383.

doi: https://doi.org/10.20546/ijcmas.2018.708.459 